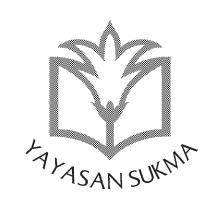

SUKMA: JURNAL PENDIDIKAN

ISSN: 2548-5105 (p), 2597-9590 (e)

Volume 3 Issue 1, Jan-Jun 2019, pp. 57-92

https://doi.org/10.32533/03104.2019

www.jurnalsukma.org

\title{
DUNIA PENDIDIKAN \\ DAN PENGEMBANGAN DAYA KREATIF
}

Fuad Fachruddin

Yayasan Sukma Jakarta, Indonesia

email: fuadfachruddin5@gmail.com

\section{Abstrak}

Arus global memberi pengaruh kuat terhadap kebijakan, praktik, dan kelembagaan pendidikan. Pendidikan dihadapkan kepada tuntutan fleksibilitas dan adaptasi untuk menyahuti tuntutan dan kesempatan dunia kerja. Kegiatan kelas (pembelajaran) hendaknya memberi peserta didik bekal yang diperlukan untuk hidup berdampingan dengan mereka yang berlatarbelakang sosio-kultural, politik, ideologi dan agama yang beragam. Daya Kreatif (creatrive power) yang mencakup berpikir kreatif, sikap kreatif (creative behavior) dan amaliah kreatif merupakan anugrah Tuhan kepada setiap individu yang diperlukan dalam menghadapi kehidupan. Pengaktualan daya kreatif 
sangat dipengaruhi banyak faktor seperti pendekatan dan model pendidikan yang diberikan. Pengembangan kreatifitas dalam kelas (pembelajaran) akan menghasilkan peserta didik kreatif dan peserta didik kreatif pada umumnya memiliki kemampuan lebih tinggi dan tangguh dibanding peserta didik biasa [tidak kreatif]. Kemampuan berfikir kreatif sebagai komponen kreatif akan menghasilkan pembelajaran efektif atau lebih jauh mengembangkan daya nalar tinggi yang dapat digunakan untuk mengatasi persoalan pembelajaran. Pengembangan potensi kreatif peserta didik akan menghasilkan superior learning. Hal tersebut akan terwujud mankala (a) guru-pendidik dibekali dengan kompetensi mengajar kreatif, (b) pemimpin sekolah memberi peluang atau kebebasan dan restu kepada warga masyarakat sekolah (guru, peserta didik, staf) mengekspresikan kreatifitasnya, (c) lingkugan fisik dan sosial dan fasilitas sarana yang mendukung terhadap penumbuhan daya kreatif peserta didik.

Kata Kunci: pengajaran kreatif, daya kreatif, berpikir kreatif, sikap kreatif

\section{A. Pendahuluan}

Kreativitas telah muncul kembali sebagai isu penting dalam merespon tantangan era global. Pemerintah, misalnya, pada 2009 yakni setelah krisis ekonomi dunia 2008, mengeluarkan INPRES No.6 tentang "Pengembangan Ekonomi Kreatif" sebagai landasan hukum untuk melakukan usaha-usaha yang diperlukan bagi pengembangan potensi kreatif warga bangsa dalam menghadapi tantangan kehidupan yang sangat kompetitif (global). Kementrian Pendidikan merijadikan beberapa keterampilan yang diperlukan dalam era global atau abad 21 (skills for $21^{\text {st }}$ century) seperti berfikir kritis (HOT atau high order of thinking), creative problem-solving skills menjadi target capaian 
dari program pendidikan Kabinet yang baru lalu.

Ada beberapa hal penting yang dapat dijadikan landasan program peningkatan pengembangan daya kreativ melalui satuan pendidikan sebagai berikut: Pertama, Globalisasi merupakan proses integrasi penduduk dunia menjadi satu warga masyarakat dunia (world citizen). Globalisasi merupakan proses percepatan internasionalisasi dari pelbagai dimensi kehidupan, dan terhubungkan (interkoneksi) kehidupan suatu bangsa dengan bangsa lain melalui jaringan global. Globalisasi juga dicirikan dengan tingkat kompetisi yang tinggi dan hal ini memberi pengaruh terhadap tatanan kehidupan, seperti ekonomi, politik, budaya, teknologi dan pendidikan (Sholte 2000; Cohen and Kennedy 2000; Steger 2001; Fachruddin 2008). Kedua, perubahan yang terjadi dalam dunia berjalan secara cepat dan menuntut setiap orang secara konstan dapat menyelesaikan tugas dan persoalan dengan cara baru. Era ini menuntut orang untuk selalu belajar (belajar seumur hidup) untuk mengupdate apa yang dimiliki dan orang perlu memikirkan cara-cara baru dalam menghadapi persoalan kehidupan. Persoalan hidup yang ditemukan di lingkungan keluarga, masyarakat atau bangsa lebih komplek yang menuntut kita untuk berfikir kreatif dan divergent dalam menyelesaikannya [termasuk konflik] (Robert Sternberg 2007; Caudeli 2003; Hick 2003; Cropley 1997). Dalam merespon perkembangan kehidupan yang cepat (ilmu dan teknologi), suatu bangsa seperti Indonesia memerlukan pemikir-pemikir kreatif dan teknokrat kreatif. Pada sisi lain kreatif atau kreativitas merupakan satu representasi karakter dan penumbuhannya di kalangan warga bangsa akan memberikan makna terhadap peningkatan harkat dan martabat bangsa (manusia).

Ketiga, lapangan kerja yang akan diisi oleh anak-anak kita yang masih menempuh pendidikan belum juga nampak jelas. Sementara itu apa yang diberikan sekolah, yaitu pengetahuan dan keterampilan, tidak dapat secara serta merta atau langsung diterapkan dalam sebagian kehidupan mereka. Keterampilan dan pengetahuan yang diperlukan untuk kehidupan (dunia kerja) mendatang tidak diketahui secara pasti pada saat 
ini (sekarang). Oleh sebab itu, pengetahuan yang diwariskan kepada anak bangsa perlu inovatif dan adaptif terhadap perubahan yang terjadi. Para peserta didik perlu dibekali dengan pengetahuan dan keterampilan yang adaptif terhadap perubahan (kemajuan). Sementara itu, masyarakat sangat membutuhkan warganya yang memiliki karakter inventif, bermanfaat, cekatan (fleksibel) dan adaptif dalam menghadapi perubahan-perubahan yang cepat. Kemampuan sekolah mengembangkan kemampuan berfikir kreatif di kalangan peserta didik mempunyai peran sangat penting (Cropley 1997), karena pendidik merupakan determinan dalam pelaksanannya. Untuk itu, kemampuan professional para pendidik yang meliputi content, pedagogical skill dan soft skills (yang termasuk kreatif, menghargai identitas diri sendiri sambil menghargai identitas orang lain) perlu terus ditingkatkan melalui berbagai skema progam agar para pendidik kita memiliki kemampuan tingkat dunia (globally competent teachers). Keempat, kreativitas merupakan "kekayaan pribadi" (personal properties) merupakan anugrah Yang Maha Kuasa yang diwujudkan dalam sikap atau karakter seperti fleksibel, terbuka, otonom, lapang dada, keinginan mencoba sesuatu (penasaran), firm (strong minded), kemampuan menjabarkan gagasan, kemampuan menilai diri sendiri secara realistis (mengenal dirinya = 'arafa nafsahu) yang kesemuanya diperlukan (prasyarat) untuk memunculkan kreaifitas. Kelima, kesehatan mental dan kreativitas. Ide tentang relasi antara kreatifitas dan kesehatan mental merupakan isu lama dalam psikologi. Konsep diri (self) dan aktualiasi diri (self actualization) merupakan kunci atau jantung dari pengembangan kepribadian yang sehat. Maslow (1954, 1971) dan Rogers (1961), dalam studi klasiknya, menekankan pentingnya sikap atau karakter "terbuka, fleksibel dan toleran" bagi kesehatan mental. Dengan kata lain, menumbuhkan atau mengembangkan potensi kreatif individu warga masyarakat akan meningkatkan kesehatan mental khususnya dalam pengertian "aktualisasi diri" (Cropley 1997; Fisher and Williams 2004).

Beberapa ahli sepakat bahwa pendidikan merupakan kunci yang sangat diharapkan dapat memainkan peran dalam 
menjawab tuntutan era global atau abad 21. Dunia pendidikan dihadapkan kepada tuntutan seperti fleksibilitas dan adaptif, misalnya, untuk menyahuti tuntutan dan kesempatan dunia kerja-meningkatkan kemampuan pekerja. Sekolah dan pembelajaran hendaknya memberi bekal yang diperlukan untuk hidup berdampingan dengan mereka yang berlatar-belakang sosio-kultural, politik, idiologi dan agama yang berragam. Pembelajaran dapat membantu mengokohkan sense of identity dalam keragaman afiliasi pandangan, faham atau idiologi (Burbules and Torres 2000, 20-22; Cohen and Kennedy 2000).

Berdasarkan pertimbangan tersebut di atas, pengembangan kreativitas dalam dunia pendidikan (pembelajaran kreatif, sekolah kreatif, guru kreatif, pimpinan sekolah kreatif, dan murid kreatif serta lingkungan yang kondusif terhadap penumbuhan kreatifitas) penting mengingat dunia pendidikan kita masih dihadapkan kepada persoalan mendasar, misalnya pemerataan mutu hasil pembelajaran, mutu pembelajaran, akses pendidikan bermutu bagi seluruh warga bangsa, kompetensi guru, dan sumber pendidikan serta keadaan geografis. Kemampuan mengubah persoalan atau keterbatasan yang ditemukan dalam penyelenggaraan pendidikan di tingkat kelas (pembelajaran) pada satuan pendidikan akan menjadi energi dan pendorong bagi pengembangan potensi kreatif (aktual) di kalangan masyarakat sekolah dan merupakan bagian penting dalam menyiapkan warga bangsa menghadapi tantangan global. Oleh sebab itu, pembelajaran yang mendorong tumbuhnya kreatifitas, berfikir kreatif, kemampuan memecahkan masalah secara kreatif (creative problem solving), pembelajaran berbasis masalah, konsep dan pendekatan "limit to reach unlimited (dalam keadaan terbatas dapat melahirkan karya luar biasa)" menjadi signifikan dalam mengembangkan pembelajaran kreatif dan menfasilitasi pembentukan warga bangsa yang kreatif.

\section{B. Sekolah dan Pengembangan Daya Kreatif}

Pendidikan global muncul sebagai upaya mempersiapkan 
generasi muda agar mereka siap menghadapi kehidupan dunia yang sarat dengan tantangan dan saling keterkaitan satu bangsa dengan bangsa lain, satu dimensi kehidupan dengan dimensi lainnya. Sekolah atau institusi pendidikan menyiapkan generasi muda dapat hidup kreatif dan bekerjasama dalam menghadapi problematika global.

Pada sisi lain, kondisi global ini telah mendorong perkembangan disiplin ilmu yang memberi kekuatan untuk keluar dari pakem menuju pemahaman sistim dan dinamika global (dunia saling berhubungan) (Gaudelli 2003). Pendidikan global mengkampanyekan perubahan cara pembelajaran yang tradisional, rote pedagogy, ke konsep dan model pembelajaran konstruktif dan multidisiplin. Perubahan pemahaman pedagogi ini diperlukan untuk memberi bekal peserta didik keterampilan dan kemampuan (aptitude) yang diperlukan dalam kehidupan global yaitu learning is self-motivated and directed; yang menekankan pada pemenuhan kebutuhan peserta didik dalam pelbagai dimensi, yaitu estetika, moral, emosi, fisik dan spiritual dalam kehidupan global, intelektualitas, membangun pengetahuan dalam proses pembelajaran yaitu interaksi dinamis antara guru-pendidik, peserta didik dan sumber informasi yang berlimpah ruah (Gaudelli 2003). Guru-pendidik harus mampu menanamkan pesan (kesadaran) yang terkandung dalam materi seperti pemerataan, keadilan, menghargai hak-hak orang lain, kerjasama dan saling ketergantungan. Guru-pendidik memberi peserta didik peluang membangun pengetahuan dan perspektifnya tentang topik atau area kajian. Untuk itu, guru-pendidik harus dibekali dengan beratus gagasan, kemampuan tentang bagaimana mengajarkan dimensi globalitas termasuk kemajmukan manusia (human diversity) yang merupakan ide pokok pendidkan global (kreatif).

\section{Pengajaran dan Pembelajaran Kreatif}

Kreatif merupakan fitrah yang dianugrahkan Tuhan kepada setiap individu insan. Namun, tidak semua orang dapat mengem- 
Dunia Pendidikan dan Pengembangan Daya Kreatif

bangkan potensi kreatif secara optimal. Pola didik atau asuh orang tua/guru terhadap anak atau peserta didik yang tidak tepat alias keliru, lingkungan keluarga atau rumah dan sekolah yang kurang/tidak mendukung atau tidak memberi peluang kepada anak atau peserta didik untuk menjadi kreatif merupakan faktor penghambat.

\section{Daya dan Proses Tumbuh Kreatif}

Dalam literatur psikologi terdapat lebih dari 60 (enam puluh) pengertian atau definisi kreatif. Kata kreatif dalam bahasa Latin creatus, secara literar berarti to have grown (telah atau menjadi tumbuh atau berkembang), dan créativité dalam bahasa Perancis. Istilah kreatif mencuat kembali setelah Perang Dunia II, sebelumnya kata-kata "invensi, discovery, dan imajinasi" lebih dikenal dalam masyarakat dunia. Mulanya kreatifitas hanya menjadi kajian atau riset di kalangan psikolog, sosiolog, teoritisi budaya yang terutama melakukan kajian (riset) tentang asal muasal pemikiran dan tindakan kreatif. Namun, belakang ini kreatifitas menjadi perhatian para ekonom terutama yang melakukan riset tentang kreatifitas dalam kontek penumbuhan inovasi dan sumber kewirausahaan. Bahkan kini kreatifitas diyakini dapat menjadi faktor pendorong pertumbuhan ekonomi, kesejahtraan masyarakat dan pembangunan yang berkesinambungan (sustainable development) (Hui, Chung-hung and Mok 2005; Howkin 2002; UNDP 2008).

Literatur yang diperoleh menunjukkan beragam pendapat atau pengertian tentang kreatif dan keragaman pengertian tersebut sangat dipengaruhi oleh sudut pandang dan latar belakang keilmuan seseorang (pakar). Kreavitas adalah proses melahirkan ide atau konsep baru atau sesuatu yang baru, atau mengintegrasikan ide atau konsep dengan penerapannya (validasi) yang menghasilkan produk orisinal dan baru (novelty) yang bernilai bagi pembuatnya dan dinilai bernilai oleh orang lain. Kreatif adalah kemampuan melahirkan sesuatu yang unik. Kreatifitas adalah kombinasi antara kemampuan, keterampilan 
dan sikap. Kreatifitas adalah cara berfikir dan bertindak atau membuat sesuatu yang original (Mayaski 2009). Gardner sebagaimana dikutip Fisher (2004) berpendapat kreatif merupakan kemampuan memecahkan persoalan, membuat produk dan melahirkan pertanyaan. Para ahli lainnya memahami kreatif sebagai state of mind dan proses imaginative yang menghasilkan produk original dan mempunyai nilai (Fisher 2004).

Kreatifitas mengandung nilai pendidikan bagi manusia karena kreatifitas akan menambah pengetahuan dan atau pengalaman bagi manusia, kendati sesuatu yang baru pada saat dimunculkannya mungkin belum dihargai oleh orang lain atau berguna bagi fihak lain. Ketika seseorang melakukan tindakan kreatif atau memiliki ide kreatif, bisa saja dia mendapatkan atau tidak memperoleh penghargaan atau pengakuan orang lain. Karena apa yang dia (orang kreatif) miliki melampaui atau melebihi batasan pemahaman dan target yang ditetapkan orang lain (diluar jangkauan). Kelebihan seperti ini dianggap aneh oleh orang lain. Misalnya, anda mempunyai gagasan 'gila' atau formula atau resep sendiri yang sangat jauh berbeda dengan kebiasan orang lain untuk mengangkat sekolah anda ke tingkat unggul (excellence).

Kreatifitas merupakan hasil dari percampuran interaktif antar pengetahuan, kemampuan intelektual, gaya berfikir (thinking style), kepribadian, motivasi dan linkungan. Motivasi terdiri dua jenis yaitu intrinsik dan ekstrinsik. Motivasi intrinsik dan dorongan dari dalam mempunyai peran sangat penting bagi kelangsungan (sustainabilitas) usaha-usaha yang diperlukan untuk mencapai hasil atau produk kreatif (Ward 2007). Dalam kreatif terdapat kemampuan imajinatif atau imajinasi. Imajinasi adalah kemampuan memikirkan atau mengeluarkan sesuatu yang mungkin dan bukan sesuatu yang actual. Imajinasi terkait dengan kemampuan menggunakan the subjunctive mood. Kekayaan dan keragaman kemampuan memikirkan suatu yang mungkin merupakan sumber kreatifitas dan generativtas dalam berfikir seseorang (Craig and Deretchin 2011, 7). Dengan kata lain, Kegiatan imajinatif adalah proses melahirkan sesuatu yang 
asli. Dengan imajinasi kita dapat menghadirkan fikiran atau otak kita dalam imaji dan ide yang sebelumnya belum terpikirkan.

Kreatif dapat juga berbentuk kemampuan memprediksi, merencanakan dan mengantisipasi akibat atau konsekwensi mendatang dari suatu tindakan. Kreatif merupakan perpaduan antara percaya diri, kesadaran dan kompetensi yang dapat menunjang keberhasilan dalam kehidupan. Selain itu, kreatif merupakan adventurous thinking, yang dicirikan dengan keberanian melepaskan diri dari pakem [out of the box], terbuka terhadap pengalaman baru dan membuka diri terhadap pilihan atau alternative (Fisher 2004). Kreatif atau kreatifitas tumbuh melalui proses sebagai berikut: Pertama kreatif diwujudkan melalui melahirkan sesuatu. Pada tataran yang sangat sederhana kreatifitas berwujud membuat, membentuk atau melahirkan sesuatu. Kedua kreatif diwujudkan dengan kemampuan menghasilkan sesuatu yang bervariasi [diferensiasi]. Mengulangi apa yang sudah dilakukan tidak termasuk dalam kategori kreatif. Seorang guru kreatif, misalnya, tidak hanya mengulang-ngulang model pembelajaran yang dinilainya efektif, namun akan menambah dan membuat variasi model pembelajaran yang diterapkannya (mengembangkan). Guru kreatif selalu melakukan refleksi terhadap yang dilakukan di kelas (pembelajaran) dan mengekplorasi proses yang dilakukan untuk mendapatkan pengetahuan dan cara-cara baru bagi pengembangan pembelajaran. Guru kreatif akan menjadikan pengembangan kreatifitas dan menumbuhkan rasa percaya diri di kalangan peserta didik bahwa mereka akan dapat berhasil dalam pembelajaran sebagai dasar (parameter) penilaian sekolah (bermutu atau efektif). Juga untuk menjadi seseorang (guru) kreatif diperlukan keberanian mengambil resiko karena apa yang ia miliki (gagasan, sikap, tindakan atau produk) berbeda dengan mainstraim yang ada. Ketiga, kreatif diwujudkan dalam originalitas [keaslian]. Yaitu sesuatu yang dilahirkan seperti gagasan, produk dan amaliah menjadi kejutan (temuan yang fantastik). Kita tidak akan disebut kreatif, apabila kita mengerjakan sesuatu dengan cara yang sama. Namun apabila kita melakukan yang belum dilakukan 


\section{Fuad Fachruddin}

atau memiliki pemikiran yang belum dipikirkan orang lain, atau dinilai original, maka apa yang kita lakukan dan miliki disebut kreatif sejati. Atau dengan kata lain, suatu tindakan disebut kreatif apabila melahirkan sesuatu yang baru (novel), asli atau unik (Starko 2010; Fisher and Williams 2004).

Dari uraian tersebut diatas, kita dapat memilah kreatif atau kreatifitas dalam 3 (tiga) dimensi sebagai berikut: Pertama, berfikir kreatif yaitu melahirkan gagasan, konsep, harapan, tujuan baru serta pemahaman baru terhadap masalah (Lebih lanjut akan dibahas dalam sub bagian berfikir kreatif dan berfikir kritis). Kedua, sikap atau prilaku kreatif (creative behavior) yaitu sikap yang mendukung atau menfasilitasi proses kreatif seperti percaya diri. Prilaku kreatif merupakan fondasi berfikir kreatif dan amaliah kreatif. Oleh sebab itu, prilaku kreatif atau lebih dikenal dengan 'prilaku konstruktif (constructive behavior)', yang mempunyai peran utama atau menjadi pendorong utama terhadap lahirnya pemikiran dan tindak kreatif. Ketiga, tindakan atau amaliah kreatif yaitu melakukan sesuatu yang baru (pengetahuan dan keterampilan) atau melahirkan produk satu-satunya pada waktu itu atau sesuatu yang sama sekali baru di masyarakat atau di dunia (Craft 2005; Fisher and Williams 2004).

Dari literatur diperoleh tiga kriteria yang dapat dijadikan dasar untuk menilai sesuatu itu kreatif atau kreatifitas yaitu orisinalitas, novelty and appropriateness (ketepatan atau kegunaan). Sesuatu dikatakan kreatif apabila orisinal dan baru (novel) sebagaimana diungkapkan dimuka. Ketepatan atau sering disebut dengan relevansi merupakan kriteria ketiga (Starko 2010) yang diterjemahkan dalam "manfaat atau kegunaan" dalam kontek positif [etika]. Bagi praktisi profesional, kreatifitas didefiniskan dengan "membuat sesuatu yang baru (novel), yang bermanfaat yaitu memungkinkan seseorang mendapatkan solusi inovatif atau unik (Weintraub 1998). Kreatifitas merupakan usaha yang bertujuan menjadikan sesuatu lebih baik dan berarti serta lebih indah. Dalam menilai kreatif kriteria tersebut perlu dilihat dari kontek budaya dan siapa yang menjadi subjek kreatifitas tersebut. Oleh sebab itu, ketika kita menilai kreatifitas seorang 
anak, misalnya, kita perlu menetapkan berdasarkan kriteria tertentu, misalnya, perkembangan atau pertumbuhan anak, juga lingkungan sosio kultural sekolah dan masyarakat. Seorang anak dinilai kreatif apabila ia mampu menyampaikan suatu gagasan atau usaha memecahkan suatu masalahnya (Starko 2010). Dalam suatu lingkungan yang diwarnai budaya paternalistik secara dominan, keberanian mengajukan pertanyaan kritis dapat dinilai kreatif.

\section{Unsur-Unsur Utama Kreatitivitas}

Dalam kreatifitas terdapat beberapa elemen utama, yaitu: Pertama motivasi, yakni mengandung hasrat akan sesuatu dan tujuan dari yang dilakukan. Motivasi diperlukan untuk memberikan nilai terhadap usaha kreatif. Kreatifitas seseorang perlu diberi asupan [intake] berupa dorongan internal dan eksternal. Meski demikian motivasi dari dalam (intrinsik) merupakan faktor yang mempunyai peran lebih dalam mewujudkan kreatifitas. Kedua Inspirasi yakni diinspirasai oleh sendiri atau orang lain. Kreatifitas dapat mengembangkan keingintahuan, melahirkan input baru (segar) dan memperkaya pengetahuan. Menumbuhkan keingintahuan kepada anak-anak merupakan langkah awal menuju kehidupan yang kreatif. Ketiga adalah gestation [pengembangan] yakni memberi kesempatan [peluang] untuk memunculkan ide kreatif. Insight dan intuisi berhubungan dengan kreatifitas dan memerlukan waktu untuk mewujudkan kreatifitas. Creative insight acapkali terlahir melalui proses yang tidak disadari dan berada dibawah tingkat kesadaran. Keempat collaboration, yakni dukungan dari mitra belajar atau masyarakat. Seseorang akan lebih kreatif apabila ia mendapat dukungan dari orang lain (Fisher and Williams 2004).

Sementara itu, Cropley (1997) menyebut empat hal yang diperlukan untuk mengaktualkan potensi kreatif, yaitu: Pertama, seseorang memiliki pengetahuan dalam bidang tertentu yang diperoleh misalnya melalui penerapan conventional learning skills. Ini merupakan prasyarat bagi seseorang untuk menjadi kreatif. 
Kedua, ada bakat atau talenta. Talenta adalah kombinasi antara sensori, motor dan kemampuan intelektual yang menyebabkan seseorang dapat menghadirkan kemampuan atau keterampilan yang luar biasa. Ketiga, usaha besar (great effort) dilakukan untuk menghasilkan produk. Seorang kreatif memiliki motivasi tinggi. Dengan motivasi tinggi, seorang yang kreatif mendorong dirinya memiliki kepercyaan diri yang tinggi bahwa ia akan dapat mencapai tujuan atau maksud yang ingin diraih (expectation of mastery). Motivasi tinggi dan percaya diri melahirkan sifat "lapar atau haus" akan pengalaman atau obsesif dengan ide atau tugas. Keempat, kesempatan yang tersedia. Potensi kreatif seorang akan mucul (actual) apabila seseorang diberi kesempatan. Cropley menyebutkan tiga hal atau komponen yang dapat memperkaya pandangan Fisher dan Williams, yaitu pengetahuan, talenta dan usaha keras atau maksimal untuk mewujudkan potential kreatif (menjadi aktual).

\section{Jenis Kreatifitas}

Terdapat beberapa jenis kreatifitas, yaitu fluid, crystallized, mature dan eminent. Fluid creativity salah satu jenis kreatifitas yang ada pada setiap orang dan menunjuk kepada tindakan yang dasar (sederhana), seperti menulis kalimat sederhana. Kemampuan kreatif ini berlangsung tidak lama. Crystallized creativity sama dengan kemampuan memecahkan masalah. Kemampuan kreatif dalam kontek ini berragam tergantung pada kompleksitas masalah yang akan dipecahkan. Mature creativity menangani persoalan yang komplek dengan originalitas, yang biasanya memerlukan keahlian yang dalam tentang masalah yang digarap. Eminent creative berkaitan atau mengaddress masalah yang cukup penting untuk melahirkan perubahan dalam bidang yang dikaji (shift in the discipline) (Starko 2010; Weintraub 1998).

Mayaski (2009) and Craft (2002) membedakan dua jenis kreatifitas dengan label C (besar) dan c (kecil). Kreatif dalam C besar atau high creativity mewujudkan sesuatu yang betul-betul baru dan telah memperoleh pengakuan (social validation) bahwa 
yang dihasilkan itu memang baru sama sekali dan melahirkan perubahan tingkat dunia, seperti temuan lampu oleh Thomas Alva Edison. Kreatifitas dalam c kecil atau little creativity adalah ide atau produk baru hanya untuk orang yang bersangkutan. Kreatifitas ini digerakkan oleh "possibility thinking" dan terdapat unsur fleksibilias, intelligence dan novelty namun karya yang dihasilkan tidak mencapai derajat luar biasa, misalnya penggunaan finger paint berwarna.

\section{Individu Kreatif}

Kalau dalam latarbelakang disebutkan bahwa kita membutuhkan orang atau pemikir kreatif agar kita sebagai bangsa dapat bersanding dan bertanding dengan bangsa lain. Oleh karena itu, menumbuhkan potensi kreatif pada masing-masing warga bangsa mempunyai arti penting untuk melahirkan seorang warga bangsa kreatif. Siapa orang kreatif? Secara sederhana Weintraub (1998) menyebutkan beberapa karakteristik orang kreatif yaitu orang yang anti meniru. Seseorang dinilai kreatif, apabila ia siap mencoba sesuatu yang baru atau baru sama sekali. Seseorang kreatif memiliki kesediaan menanggung resiko [korban] apabila usahanya tidak berhasil alias gagal atau berani mengambil resiko (Stevenson 2006). Seorang kreatif merasa antusias dan senang menggali sesuatu yang baru. Bagi seorang kreatif, resiko seperti kegagalan dapat menjadi ukuran kesenangan (Stevenson 2006). Seseorang kreatif berusaha dengan baik mengkomunikasikan gagasan atau mencari masalah dan memecahkannya. Bagi seorang pendidik, sikap-sikap atau karaker tersebut di muka perlu dilanjutkan atau ditumbuhkan dalam kelas sehingga kegiatan kreatif terjadi secara alami. Keberanian mengintroduksi pendekatan dan kegiatan kreatif memberi implikas terhadap teori dan praktek belajar di kelas (Starko 2010). Individu kreatif akan menemukan cara baru untuk melakukan sesuatu atau mempunyai pemikiran berbeda. Seorang kreatif memiliki kemampuan mengeluarkan gagasan yang segar, terbuka dan bersedia melakukan perubahan. Dengan sikap atau karakter seperti ini, seorang 
kreatif akan melahirkan atau menghasilan produk yang unik dan berbeda dengan karya yang dihasilkan oleh orang lain (Robert and Harpley 2007).

Ada beberapa ciri personal yang menunjukan seseorang kreatif. Ciri-ciri itu dikategorikan pada tiga besaran, yaitu ciri kognitif, kepribadian (personality) dan biographical events. Seorang kreatif dapat dibedakan dengan orang tidak kreatif dilihat dari beberapa hal seperti cara berfikir, nilai, temperament dan motivasi. Seorang kreatif akan menggunakan creative thinking [berfikir kreatif] untuk mengkomunikasikan ide dan memecahkan masalah. Dalam memecahkan masalah, seorang kreatif melakukan identifikasi masalah lalu mengurainya ke jenis masalah yang secara khusus memerlukan penyelesaian (pemecahan). Dalam penemuan masalah, kita akan menemukan jenis kreatifitas yang muncul dari seseorang (Starko 2010). Kepribadian seseorang kreatif dapat dilihat dari kecerdasannya dalam menyelesaikan tugas atau pekerjaan yang sulit, selalu mencari perbaikan atau perubahan dan senang melakukan pencaharian gagasan, dan tidak suka mengikuti hal atau cara yang konvensional (Cropley 1997).

\section{Guru dan Pimpinan Sekolah Kreatif}

Di muka telah disinggung karakter atau karakeristik guru kreatif, AI-Girl (2007) memberikan penjelasan tentang guru kreatif. Guru kreatif adalah seorang yang menguasai keilmuan (expert), memiliki otonomi di kelas (pembeljaran). Guru kreatif menetapkan tujuan, maksud, membangun kemampuan dasar (basic skills), mendorong pencapaian pengetahuan tertentu, menstimulasi keingintahuan dan eksplorasi, membangun motivasi, mendorong percaya diri dan berani mengambil risiko, fokus pada penguasaan ilmu dan kompetisi, mendukung pandangan positif, memberikan keseimbangan dan kesempatan memilih dan menemukan, mengembangkan pengelolaan diri (kemampuan atau keterampilan metakognitiv), menyelenggarakan pembelajaran dengan menggunakan berbagai teknik dan strategi 
untuk menfasilitasi lahirnya tampilan [perwujudan] kreatif, membangun lingkungan yang kondusif terhadap tumbuhnya kreatifitas, dan mendorong imajinasi dan fantasi. Guru kreatif akan memberikan inspirasi kreatif kepada peserta didik (Fisher 2004). Cropley (1997) menyebutkan cirinya sebagai berikut: fleksibel, luas pangaweruh dalam menyajikan materi dan menemukan cara penyajian kepada anak (peserta didik) yang membuat mereka senang terlibat (partisipasi). Guru kreatif mampu membangun hubungan yang menyenangkan dan dengan konsisten mengembangkan berfikir divergent di kalangan muridnya. Juga guru kreatif tidak bersikap manut tapi kritis dalam relasi dengan koleganya. Guru kreatif suka mengembangkan kritik terhadap dirinya, sikap dan perasaan yang tidak sepakat (kritis) terhadap sistem yang berlaku (Fisher and Williams 2004). Guru kreatif memberikan bimbingan dan mengarahkan peserta didik kepada tujuan (focus). Guru kreatif memilik sensitifitas dan kesadaran terhadap situasi yang ada. Guru kreatif akan melawan setiap sikap dan tindakan yang menghina atau mengecilkan peserta didiknya (Jeffrey and Woods 2003).

Guru kreatif akan muncul di lingkungan manakala kepemimpinan pendidikan (sekolah) yang kreatif tumbuh. Pemimpin sekolah yang kreatif akan memberikan peluang atau kebebasan dan restu kepada warga masyarakat sekolah (guru, peserta didik, staf) mengekspresikan kreatifitasnya. Pemimpin kreatif akan melibatkan berbagai fihak dalam dialog kreatif dan pembuatan keputusan yang kreatif. Pemimpin kreatif akan menjadi sumber inspirasi, memberi akses, waktu, sumber dan menciptakan lingkungan yang kondusif untuk melakukan eksperimen dan berbeda pandangan (konflik) (Fisher and Williams 2004).

\section{Peserta Didik Kreatif}

Menjadikan anak (peserta didik) kreatif merupakan salah satu tujuan dari pembelajaran. Kreatif merupakan bagian atau subset dari karakter positif dan karakter atau nilai tersebut merupakan parameter mutu pendidikan dari sisi nilai, ke- 
pribadian atau karakter. Oleh sebab itu, penumbuhan kreatif merupakan kandungan dari konsep pendidikan yang perlu diwujudkan melalui pembelajaran. Cropley (1997) menyebutkan beberapa karakteristik anak sangat kreatif (highly creative children), yaitu memiliki motivasi berprestasi tinggi, cerdas, memiliki talenta dibanding peserta didik lainnya. Anak kreatif biasanya memiliki (daya) imaji diri yang kuat dan sikap seperti ini dapat melahirkan prilaku atau tindakan yang terkadang dinilai negative oleh sebagian orang, misalnya arogan. Anak-anak kreatif memiliki keingintahuan yang tinggi dan karakter ini dapat melahirkan sikap atau perilaku positive yaitu berani mengambil resiko. Keberanian mengambil resiko tidak hanya dalam pengerian fisik, juga dalam pengetertian intelektual dan sosial.

\section{Berfikir Kreatif dan Berfikir Kritis}

Berfikir kreatif dan berfikir kritis mempunyai pengertian dan fokus berbeda, namun keduanya sangat diperlukan dalam pembelajaran. Berfikir kreatif adalah kemampuan melahirkan gagasan, konsep, kehendak dan tujuan baru; pemahaman baru terhadap masalah yang dihadapi. Potensi berfikir kreatif dapat dikembangkan melalui pelbagai proses. Pengembangan berfikir kreatif merupakan cara yang ampuh yang dapat dilakukan dengan melibatkan anak-anak (peserta didik) dalam pembelajaran melalui pelbagai cara dan pendekatan. Peserta didik yang terdorong berfikir kreatif akan memiliki motivasi dan percaya diri yang tinggi. Berfikir kreatif bertautan dengan pembuatan keputusan yakni kemampuan menetapkan nilai, gagasan dan produk. Berfikir kreatif di kalangan anak-anak (peserta didik) dapat dilihat dari beberapa hal, misalnya, kemampuan anak melahirkan karya, menunjukan imajinasi dan originalitas dan menetapkan nilai, hasil atau karya yang dilakukan. Berfikir kreatif sangat penting untuk mewujudkan pembelajaran yang sukses dan keberhasilan dalam kehidupan. Dalam pembelajaran, berfikir kreatif merupakan salah satu kunci dari pembelajaran kontekstual yaitu system pembelajaran yang dirancang membantu peserta 
Dunia Pendidikan dan Pengembangan Daya Kreatif

didik memahami arti materi pembelajaran (akademik) dan belajar serta memiliki kemampuan menghubungkan pembelajaran dengan kehidupan sehari-hari mereka. Dalam pembelajaran kontekstual, peningkatan berfikir kreatif merupakan salah satu strategi untuk membantu peserta didik belajar (Fisher 2004; Fisher and Williams 2004).

Ada beberapa muatan atau kandungan (property) dalam berfikir kreatif sebagaimana dijelaskan Cropley (1997), yaitu: (a) Sensitivitas terhadap Masalah (Problem) - Seorang kreatif menunjukan kemampuan tinggi (piawai) dalam mengidentifikasi atau menetapkan masalah. (b) Mendifinisikan kembali Masalah (problem) - Seorang kreatif mampu menguatkan (menjelaskan) kembali suatu masalah dengan istilah-istilah baru yang memberi insight baru dan pemahaman segar dengan pendekatan yang digunakannya. (c) Penetrasi- Seorang kreatif selalu memiliki kemampuan menunjukan jantung atau titik utama suatu persoalan (problem) dengan mengabaikan detail informasi yang tidak relevan. (d) Analysis dan Syntesis - Seorang kreatif memiliki kemampuan mengurai masalah kedalam bagian-bagian dan melihat hubungan antara elemen suatu masalah dengan pengalaman. (e) Ideational Fluency- Setelah menunjukan masalah, menganalisisnya dan merumuskannya, seorang kreatif secara terampil melahirkan atau menghasilkan sejumlah gagasan yang relevan. (f) Flexibility - Seorang kreatif biasanya menunjukan flexibility dan fluency. Poin ini mencakup kemampuan mengubah proses berfikir dan mencarikan pendekatan baru. (g) OriginalityAkhirnya, seorang kreatif akan menunjukan kemampuan yang tinggi dalam melahirkan sesuatu yang baru dan aneh (unusual).

Berfikir kritis juga perlu dikembangkan melalui pembelajaran, karena berfikir kritis merupakan bagian dari karakter [subset]. Berfikir kritis merupakan parameter mutu pendidikan dari dimensi nilai, sikap atau karakter. Selain itu, berfikir kritis merupakan bagian thinking skill yang menjadi bagian dari kemampuan kognitif. Ada beberapa pengertian atau definisi tentang berfikir kritis. Misalnya (a) berfikir kritis adalah kemampuan menimbang informasi dari berbagai sumber, memproses informasi 


\section{Fuad Fachruddin}

dengan cara kreatif dan logis, mempertanyakan, menganlisis dan akhirnya memutuskan kesimpulan yang akan dipertahankan dan dijadikan pegangan; (b) berfikir kritis adalah kemampuan menantang teori atau gagasan; (c) berfikir kritis adalah kemampuan mengembangkan argumen, mendekonstruksi ide atau mensintesasi pelbagai ide yang komplek dan memanfaatkan pelbagai cara untuk memperoleh kesimpulan yang sama atau berbeda terhadap isu yang sama; (d) berfikir kritis adalah proses berfikir a 3-D yaitu depth, breadth dan time; bersikap obyektif dan tidak subyektif. Berfikir kritis bukan evaluasi personal tapi refleksi yang diterapkan terhadap pemikiran atau teori orang lain. (e) Berfikir kritis adalah analisis terhadap suatu situasi berdasarkan fakta [bukti] untuk menetapkan suatu keputusan atau sampai kepada suatu keputusan (Dunn, Halonen and Smith 2008).

Dari pengertian tersebut kita menemukan hal-hal yang mendasar dari berfikir kritis. Berfikir kritis adalah aspek dari kegiatan berfikir. Berfikir kritis merupakan bentuk pembelajaran yaitu sarana untuk melahirkan pengetahuan baru dengan mengunakan 'the tools of manipulation of knowledge' (seperti analisis, pemahaman dan sintesis). Fokus berfikir kritis adalah penilaian [the assessment] terhadap bukti yang ada untuk membuat suatu keputusan. Berfikir kritis biasanya berkaitan dengan masalah/isu [subject matter] yang komplek dan memerlukan alternative pendapat atau cara pandang; serta memerlukan keterlibatan secara mendalam dalam suatu masalah/isu [subject matter] (Moon 2008, 23-24). Refleksi merupakan bagian dalam proses berfikir kritis. Refleksi menunjukan sederet kemampuan berfikir (thinking skills) yang memajukan intellectual focus, motivasi dan keterlibatan dalam gagasan baru. Kemampuan berfikir mencakup kemampuan mengenal pola-pola; memecahkan masalah dengan cara praktis, kreatif atau ilmiah; terlibat dalam nalar psikologis dan mengadopsi berbagai cara pandang [perspektif] ketika seseorang yang memiliki kemampuan berfikir kritis mengevaluasi ide atau isu (Dunn, Halonen and Smith 2008). Mengajar peserta didik berfikir kritis dalam kelas (pembelajaran) dan di luar kelas akan memperbaiki kemam- 
puan mereka mengamati, menyimpulkan, mempertanyakan, mengembangkan ide baru dan menganalisis argumen. Dalam pembelajaran, tujuan pembelajaran berfikir kritis adalah memperbaiki kemampuan para peserta didik dalam menguraikan, memprediksi, menjelaskan dan mengontrol prilaku. Para guru memerlukan alat-alat yang relevan dan strategi pembelajaran yang dapat meningkatkan kemampuan peserta didik dalam berfikir kritis (Dunn, Halonen and Smith 2008). Berfikir kritis dapat ditumbuhkan atau dikembangkan di kalangan peserta melalui berbagai kegiatan, misalnya murid diberitugas mengevaluasi obyek, mengembangkan argumen (Moon 2008, 23).

\section{Menumbuhkan Kreativitas}

Bagian ini akan membahas hal-hal yang perlu diperhatikan dalam menumbuhkan dan mengembangkan potensi kreatif atau modal kreatif yang ada di masyarakat sekolah (peserta didik, guru dan manajmen) dalam pelbagai jenjang. Juga keragaman latarbelakang sosio-ekonomi dan kultural masyarakat perlu mendapat perhatian. Juga keragaman pesoalan atau tantangan yang dihadapi oleh lembaga pendidikan per jenjang yang ada di masing-masing daerah merupakan faktor yang tidak boleh diabaikan. Kesemuanya dapat memberi pengaruh terhadap pengembangan kreatifitas pada masing-masing satuan pendidikan---bentuk dan pendekatan pembelajaran serta evaluasi pembelajaran kreatif. Oleh sebab itu, kajian secara cermat terhadap kekhasan masalah yang ada di masing-masing jenjang pendidikan di masing-masing daerah sangat penting.

Di Papua atau Kalimantan, khususnya di beberapa daerah pedalaman, misalnya, anak-anak mengalami kesulitan mendapatkan alat tulis seperti pinsil. Ketika anak-anak tersebut bermain-main sambil membakar ikan, mereka akan mendapat inspirasi (ide kreatif) dari arangyang ditinggalkan dari pembakaran ikan. Misalnya, mulanya secara iseng mereka menggoreskan arang bekas kayu pembakar ikan kertas bekas atau tanah, lantas mendapatkan goresan hitam. Dari goresan hitam, Dalam kepala 


\section{Fuad Fachruddin}

anak terlintas gagasaan atau fikiran untuk memanfaatkan arang sebagai alat tulis (pinsil). Anak-anak tersebut belajar menulis dengan pinsil buatannya sendiri. Lain halnya dengan anak-anak perkotaan yang dalam lingkungannya peralatan elektronik tidak menjadi seuatu yang aneh, merka akan memiliki ide lain atau berbeda dengan teman-teman mereka di pedalaman Papua dan Kalimantan. Anak-anak di perkotaan akan membuat game pembelajaran yang dapat digunakan teman-temannya melalui handphone sebagai perwujudan sikap dan tindak kreatif.

Dari ilustrasi tersebut, kita dapat menyimpulkan bahwa dua kelompok anak (pedalaman dan perkotaan) secara fitrah memiliki potensi dan nilai kreatif yang sama. Hanya saja aktualisasi potensi dan nilai kreatif akan dipengaruhi oleh daya dukung lingkungan dimana anak-anak tersebut tinggal. Kekhasan keadaan lingkungannya akan memberi warna terhadap karakter kreativitas mereka. Juga budaya yang ada dalam lingkungan anak-anak turut memberi corak kreatifitas-berfikir, bersikap dan bertindak.

Dua kasus contoh tentang anak-anak Indonesia yang kreatif dalam ilustrasi di muka memberi petunjuk kepada kita bahwa meski jumlah anak-anak Indonesia yang kreatif banyak namun jumlah mereka masih kecil dibanding dengan populasi anak-Indonesia. Oleh sebab itu, potensi kreatif yang dimiliki seluruh warga bangsa ini khususnya peserta didik di pelbagai jenjang dan satuan pendidikan perlu diaktualkan secara optimal sehingga menjadi modal bangsa. Bagian ini akan membahas beberapa hal yang berkaitn dengan pengembangan jiwa kreatif yaitu penciptaan atmosfir atau lingkungan kreatif, pembelajaran kreatif dan penciptaan wahana apresiatif terhadap pengembangan daya kreatif.

Kreatifitas sebagaimana disebutkan di muka mencakup tiga dimensi, yaitu prilaku kreatif (creative behavior), berfikir kreativ (creative thinking) dan tindak atau aksi kreatif (creative acts). Dimensi-dimensi kreatif tersebut dapat dikembangkan melalui sekolah. Potensi kreatif peserta didik, menurut Cropley (1997), 
Dunia Pendidikan dan Pengembangan Daya Kreatif

dapat dikembangkan dengan menggunakan pelbagai cara atau pendekatan. Para guru, misalnya, membantu peserta didik melahirkan gagasan baru (invensi dan orisinal) dengan, antara lain, menata kelas yang memberi banyak kesempatan peserta didik untuk memunculkan kreatifitas, kesediaan menerima atau toleran terhadap prilaku kreatif; mengembangkan minat peserta didik berkreasi (kreatif) dan meyakinkan mereka bahwa mereka memiliki potensi menjadi insan kreatif. Juga para guru dapat mennstimulasi kreatifitas di kelas dengan menampilkan sikap dan prilaku kreatif (seperti role model, percaya diri). Secara singkat dapat disimpulkan ada beberapa syarat yang diperlukan untuk menumbuhkan prilaku, sikap dan tindak kreatif di lingkungan sekolah.

\section{Menciptakan Iklim Kreatif}

Guru adalah determinan dalam menentukan iklim belajar. Guru harus menciptakan oase-oase dalam kelas yang dapat melindungi peserta didik dari tekanan yang muncul dalam kehidupan kesehariaan (Best Thomas 2008). Penciptaan iklim atau atmosfir kreatif dimaksudkan untuk menghadirkan suasana yang merangsang munculnya kreativitas semenjak proses menjadi dari awal yakni bentuk yang paling sederhana dan fasilitasi yang terus menerus dalam penumbuhan kreatifitas hingga berkembang dan mencapai puncak kreativitas yakni karya kreatif yang memiliki nilai dan kegunaan untuk orang banyak. Proses kreatif akan muncul pada saat seseorang berada dalam suasana (perasaan) aman, nyaman dan senang untuk menyampaikan pemikiran, mengajukan pertanyaan atau mempertanyakan sesuatu serta mengekspresikan gagasan-gagasan kreatifnya. Sebaliknya proses kreatif akan sulit berkembang apabila individu merasa tidak nyaman apalagi merasa sangat terancam atau tertekan. Untuk itu sikap, prilaku dan tindakan orang-orang yang ada sekeliling membuat individu merasa tidak aman, tidak nyaman, diabaikan, tidak dihargai, tertekan dan direndahkan perlu dihindarkan. Suasana yang kondusif sebagaimana dimaksud sejatinya 
dilahirkan dalam lingkungan sekolah, keluarga dan masyarakat. Suasana yang kondusif tersebut dapat dihadirkan melalui optimalisasi fungsi dari tiga unsur utama, yaitu guru sebagai teladan kreatif (creative role model), lingkungan fisik dan lingkungan non fisik.

\section{Guru Sebagai Teladan Kreatif (Role Model: The Creative Teacher)}

Guru adalah kunci keberhasilan pendidikan. Paulo Freire (Kincheloe 2008) terobsesi dengan pendidikan yang membebaskan jiwa manusia dari segala bentuk tekanan, kekangan apalagi "penjajahan". Orang-orang yang terbebaskan jiwanya akan dapat mentransformasi dirinya menjadi insan kreatif. Untuk itu, guru handal dapat dilihat dari keilmuaan dan komitmen terhadap pemartaban warga masyarakat sebagai praksis dari konsep pendidikan sangat diperlukan. Dalam kaitan ini guru dituntut dapat berperan sebagai teladan kreatif (creative role model) yang mengembangkan sikap dan prilaku diri dan sejawatnya yang mendorong terbentuknya suasana kondusif bagi pengembangan kreativitas anak didik. Beberapa hasil studi menunjukkan bahwa terdapat hubungan langsung antara keteladan kreatif dalam bentuk sikap atau berfikir kreatif (berfikir divergent) yang muncul dari sosok guru atau (mereka secara formal menyadarinya atau tidak disengaja) dengan tampilan berfikir divergent di hadapan peserta didiknya. Begitu halnya, peserta didik yang memiliki kemampuan berfikir divergent tinggi akan memiliki prestasi sangat baik dalam pembelajaran. Hal ini juga mempunyai hubungan dengan guru yang memiliki kemampuan berfikir divergent tinggi, kendati keduanya-guru dan peserta didikmungkin tidak begitu engeh dengan metoda atau pendekatan apa yang diterapkan untuk mendorong kemampuan berfikir divergent mereka (anak-anak didik) berkembang. Para guru yang memiliki kemampuan berfikir divergent tinggi dapat mendorong tumbuhnya kreatifitas di kalangan peserta didik, meski para guru tidak membuat suatu upaya khusus dan disengaja untuk menum- 
buhkan kreatifitas. Oleh sebab itu, teladan prilaku kreatif dari para guru merupakan suatu faktor kuat atau utama yang dapat mengembangkan kreatifitas di kalangan peserta didik (Cropley 1997).

Keteladan para guru dapat diwjudkan dengan kemampuan mengembangkan komunikasi kreatif yang berorientasi pada stimulasi pemikiran dan prilaku kreatif di kalangan anak-anak (peserta didik). Komunikasi kreatif meliputi sekurangnya lima perilaku komunikasi yaitu melayani, merangsang, menerima, mendukung dan mempromosikan. Melayani maksudnya adalah bersikap terbuka untuk melayani semua pertanyaan dan tantangan anak-anak kreatif. Guru melayani anak didik yang memerlukan respon, jawaban, bantuan dan bimbingan untuk menjalani suatu proses kreatif dengan sabar dan penuh antusias. Untuk menumbuhkan potensi kreatif peserta didik, guru (sebagai tauladan) dituntut untuk melakukan perubahan terhdap pola pendekatan dan komunikasi 'konvensional' terhadap anak didik. Para guru harus meninggalkan pola pendekatan lama yang tidak merangsang tumbuhnya jiwa kreatif anak. Guru harus membuang jauh-jauh sikap atau negative sepertii menjawab pertanyaan peserta didik sekedarnya, tidak melayani pertanyaan, menutup komunikasi sebelum tuntas, mengkritisi yang cenderung meremehkan pada saat anak didik memulai suatu proses kreatif. Sikap dan prilaku komunikasi negatif seperti itu akan melahirkan suasana tidak mendukung (discourage) bahkan akan memupuskan potensi dan proses kreatif anak didik.

\section{Lingkungan Fisik (Physiological State)}

Lingkungan fisik meliputi lingkungan fisik sekolah dan luar sekolah. Ruang/infrastruktur di lingkungan sekolah ditata menjadi lingkungan yang dapat menstimulasi siswa menjadi kreatif. Lingkungan fisik akan menstimulasi kelima indera anak didik yang menumbuhkan sikap rasa ingin tahu tinggi (curious), berpikir kritis, berpikir kreatif bahkan juga berkreasi dalam segala bentuk/ konten. Ruang /infrastruktur di lingkungan 
luar sekolah, misalnya taman, gedung, lapangan, rumah, fasilitas publik, play-ground, infrastruktur dan sejenisnya, ditata menjadi lingkungan yang membuat peserta didik berinteraksi. Lingkungan luar sekolah menstimulasi kelima indera anak didik melahirkan sikap atau prilaku rasa ingin tahu yang tinggi (curious), berpikir kritis, berpikir kreatif bahkan juga berkreasi dalam segala bentuk/ konten (isi/materi).

\section{Lingkungan Non-Fisik (Psychological State)}

Lingkungan yang kondusif akan menjadi enerji untuk memunculkan kreatifitas. Kreatifitas dalam kelas atau pembelajaran membutuhkan tidak hanya pengetahuan dan kemampuan guru dan peserta didik, juga lingkungan kelas yang dapat mengembangkan percaya diri dan keberanain. Para guru dapat memanfaatkan pengaruhnya untuk menciptakan suasana yang dapat melahirkan belajar kreatif. Untuk mewujudkan pembelajaran kreatif diperlukan kemampuan melahirkan gagasan dan kondisi emosional dan motivasional. Kondisi ini termasuk keinginan individu untuk memfungsikan diri secara kreatif. Lebih jauh lagi kreafitas memerlukan suatu lingkungan yang memberikan kebebasan kepada individu mengekspresikan ide, responsive terhadap gagasan baru yang memungkinkan anak didik dapat mengevaluasi secara bebas dari rasa ketakutan, ditolak atu dimaki. Untuk itu, guru dapat membantu menyingkirkan segala hambatan yang menghalangi kreatifitas muncul atau tumbuh yaitu membangun suatu suasana atau lingkungan yang memungkinkan anak didik dapat mengekspresikan idea atau fikirannya secara bebas (Crowley 1997; Best and Thomas 2008).

Lingkungan non-fisik tersebut meliputi berbagai kondisi sebagai berikut: Kondisi intrapersonal yang mendukung pewujudan berfikir kreatif dikembangkan ketika guru membantu anak didik memahami kemampuan berfikir divergent dan percaya diri, kendati ada gerakan kontra pengembangan kreatifitas. Kondisi emosional untuk memunculkan kreatifitas perlu dikembangkan atau ditingkatkan ketika guru mendorong anak didiknya 
menyadari dan menghargai perasaan anak didik. Pada waktu bersamaan, motivational climate yang mendukung tumbuhnya berfikir divergent ditumbuhkan ketika kecemasan menurun dan perasaan merasa terancam mulai tersisih. Salah satu caranya adalah meningkatkan keadaan interpersonal yang mendukung daya berfikir kritis tumbuh. Misalnya, guru mendorong anak didik yang kreatif menyajikan gagasan yang relevan dengan tujuan orang lain. Pada waktu bersamaan, anak didik dibimbing untuk dapat mengekspresikan kritik terhadap ide orang lain dengan cara yang konstruktif dan positif. Guru tidak hanya membantu kelompok anak didik yang kreatif juga membantu orang tua mereka memahami bahwa anak-anak mereka berbeda dibanding dengan anak-anak lain (kreatif). Guru hendaknya memainkan peran untuk mengatasi faktor-faktor yang akan mengahalangi lahirnya kemampuan berfikir divergent dengan (a) mengeleminasi sanksi negative terhadap fihak yang melawan fikiran divergen; (b) mengurangi perasaan khawatir "betul atau tidak betul" ide, karya dan tindak individu; (c) mengatasi perasaan putus atas dan rasa teralinasi (atau tidak mempunyai arti=meaningless) di kalangan mereka yang memiliki kemampun berfikir divergent yang tinggi; (d) mencegah ejekan atau cercaan dari kelompok; (e) mengurangi kesalahfahaman dan rasa putus asa dengan orangtua. Iklim atau lingkungan non fisik yang mendukung kreatifitas tidak hanya memerlukan eliminasi unsur-unsur negative atau penghalang terhadap muncul atau berkembangnya kreatifitas, juga menghadirkan faktor-faktor positif, misalnya (a) sensitif terhadap perasaan dirinya; (b) menaruh perhatian terhadap pengalaman sensori; (c) terbuka terhadap gagasan baru; dan (d) menghargai gagasan baru atau gagasan aneh (Cropley 1997).

\section{E. Pengajaran dan Pembelajaran Kreatifitas (Teaching and Learning Creativity)}

Pembentukan perilaku kreatif termasuk berpikir kreatif membutuhkan suasana/iklim yang mendukung. Fasilitas diawali dengan pemikiran tentang software berupa perancangan modul 


\section{Fuad Fachruddin}

kurikulum, tujuannya, sasaran yang akan dicapai, metode dan teknik melaksanakannya dan evaluasi pelaksanaan modul tersebut. Selain itu untuk mewujudkannya dalam aktivitas operasionalnya dibutuhkan hardware, berupa sarana pendukung fisik dan non-fisik. Sasaran dari pengajaran dan pembelajaran kreatif adalah melakukan perubahan (transformasi) terhadap sikap pasif ke bersikap, berfikir dan dan bertindak kreatif. Peserta didik diharapkan dapat mencapai perubahan sikap imelalui proses pembelajaran yang tepat, baik dalam materi, pendekatan dan metoda pembelajaran. Sikap seorang kreatif dicirikan dengan sejumlah karakter, misalnya rasa ingin tahu yang kuat untuk memperoleh jawaban akan segala hal yang diamati dan dipikirkannya, sikappdan dan pandangan terbuka ke segala fenomena yang diamati (open minded), tekun, motivasi intrinsik yang kuat dan memiliki daya tahan (endurance) untuk terus berpikir sampai mencapai hasil pemikiran misalnya berupa gagasan atau produk nyata. Juga pesera didik memiliki karakter fleksibel dalam pengertian lincah berpikir dari satu dimensi ke dimensi pemikiran lainnya, lancar dan mudah menghasilkan ide yang mengalir, menggunakan cara berpikir lateral atau divergen.

Sikap kreatif merupakan proses mental yang dapat menghasilkan suatu karya kreatif atau inovatif yang bermanfaat dalam wujud benda atau non benda dengan syarat bahwa ada fasilitas lingkungan yang tersedia untuk penciptaan itu. Oleh karena itu dalam proses pembelajaran siswa agar menjadi bermental kreatif, mereka perlu diarahkan untuk selalu mengasah proses mental tersebut dan diberikan pula kesempatan dan fasilitas untuk tumbuh kembangnya daya kreatifitas itu. Proses pembentukan ini dapat dilakukan dengan beberapa pendekatan tergantung pada operasionalisai konsep kreatif dan kontek kemampuan yang ingin dicapai. Beberapa definisi yang digunakan adalah: terciptanya ide baru yang orisinil (adakalanya definisi tersebut dianggap rancu. Misalnya apakah ide yang diperoleh dari hasil modifikasi dari apa yang sudah ada sebelumnya dapat dikatakan orisinil/asli atau kreatif), suatu karya baru yang bermanfaat bagi kehidupan manusia, kombinasi ulang (recombination) dari karya 
karya lain sebelumnya, dan lain sebagainya.

Perbedaan pengertian ini membawa konsekuensi pada metode dan teknik yang berbeda dalam pembelajarannya. Metode dan teknik pembelajaran ini harus mempertimbangkan cara penyampaian/pemberian yang membentuk proses mental kreatif. Sebagai suatu contoh metode yang memfasilitasi terbentuknya proses kreatif melalui apa yang disebut Prinsip Kerja Kreatif. Prinsip kerja kreatif dicirikan dengan, misalnya, mengamati proses pembelajaran yang terjadi secara total antara olah raga-olah pikir-olah rasa-olah hati; terjadi secara acak dengan perjalanan mulai dari ide/gagasan - kemudian proses- sampai hasil akhir; menggunakan logika, rasa, imajinasi, intuisi; proses pernyataan (konkritisasi) dari pergumulan yang bersifat abstrak menjadi sebuah berbentuk; relatif (bahkan subyektif) sudut pandang atau perspektifnya. Kerja kreatif berorientasi pada proses yang berkesinambungan dan hasil akhir merupakan kesimpulan sementara; dan terbentuknya kesadaran baru merupakan hal yang sangat penting. Pendekatan lain misalnya metode yang disebut cooperative-holistic, yang menggunakan pendekatan Neo Humanistic Education (NHE-Learning), yang mengikuti proses bertahap dimulai dari Orientasi, Eksplorasi, Partisipasi, Interaksi, Social Skill: Kepemimpinan.

Apapun pendekatan yang digunakan untuk menumbuhkan sikap dan motivasi berpikir dan berprilaku kreatif, penerapan berjalan berproses atau bertahap sesuai dengan perkembangan anak didik menurut jenjangnya (PAUD, Pendidikan dasar dan Pendidikan Menengah). Arti bertahap juga dimaksudkan sebagai adanya pertimbangan pembentukan sikap yang dimulai dari pembentukan prilaku atau sikap Kreatif sampai dengan bertindak kreatif dan menghasilkan produk kreatif. Metode dan teknik pengajaran dan pembelajaran ini harus pula didukung oleh beberapa persiapan dan fasilitas agar tujuan 'pendidikan kreatif" tercapai, seperti kondisi eksternal seperti wahana yang memicu proses kreatif, fasilitator yang dapat menggugah proses kreatif, sarana fisik dan non-fisik yang menstimulasi siswa untuk berpikir kreatif, networking atau jejaring yang memudahkan 
akses untuk bertindak kreatif, dukungan orang tua, dan sistem pendidikan yang memberdayakan pengajaran pembelajaran kreatif. Juga kondisi internal dalam proses mental siswa yang mencirikan adanya perasaan rileks-bebas-bermain, proses berpikir divergen, pembentukan sikap-minat-motivasi untuk berkreasi, dan munculnya Kesadaran Baru sebagai hasil proses belajar.

\section{Peningkatan Kreatifitasi di Kalangan Anak-Anak}

Mayeksi (2009) menjelaskan bahwa dua hal yang perlu diperhatikan dalam menumbuhkan kreatifitas pada anak didik, yaitu perkembangan (developmental level) dan perbedaan individu. Tingkat perkembangan tingkat pertumbuhan fisik, sosial, emosi dan intelektual. Perbedaan individu adalah tingkat perbedaan tentang kemajuan yang dicapai oleh masing-masing dalam suatu area. Misalnya, apa yang menjadi kekhususan, minat, kemampuan, keterampilan yang telah berkembang; keadaan keluarga. Keduanya menjadi komponen praktek perkembangan yang tepat (developmentally appropriate practice). Maya membedakan pendekatan dalam mengembangkan kreatif anak pada usia dini dan usia kelas 4 atau 5 sekolah Dasar atau upper elementrary schools. Meski demikian untuk mengembangkan kemampuan kreatif diperlukan pengetahuan dan keterampilan. Misalnya, guru PAUD akan memberi pengetahuan dan keterampilan serta lingkungan yang mendorong tumbuhnya berfikir kreatif di kalangan anak didiknya.

Peningkatan keatifitas pada anak-anak dilakukan melalui metode bermain dan eksplorasi. Misalnya, guru mengajak anak didik bermain komputer yang terlebih dilkukan melalui eksplorasi untuk menemukan, misalnya, apa yang dapat dilakukan dengan komputer. Lamanya eksplorasi tergantung kepada frekwensi eksposure anak didik dengan kurikulum. Dibekali dengan keterampialan, anak-anak didik merasa enak menggunakan mouse, misalnya, lantas mereka benar-benar mulai memainkan computer. DEngan cara itu, anak didik mendapat pengetahuan dan 
keterampilan melalui pengalaman formal. Anak-anak mengeksplorasi dan bermain dengan bahan atau materi di lingkungan dan kegiatan tersebut dan kegiatgan tersebut membentuk 'the brain' (Coleman 1995; Anetta et.al. 2011).

Selain itu, juga harus didukung dengan sikap peneriamaan secara positif (promoting creativity through positive acceptance). Penerimaan positive terhadap anak didik dilakukan dengan antara lain, guru menunjukan secara terbuka kepada anak didik bahwa prilaku ingin tahu, eksplorasi dan prilaku sejati mempunyai arti penting. Guru memberi peluang kepada anak didik ketika anak-anak didik melakukan kegiatan yang menarik dan menjadi minat mereka. Guru membiarkan anak didiknya melakukan kegiatan sampai mereka merasa bahwa pekerjaan sudah selesai atau rampung. Guru membiarkan atau memberi kesempatan anak didiknya memikirkan cara melakukan sesuatu apabila mereka memilih membuat sesuatu tindakan. Menciptakan suasana rilek juga dapat dilakukan oleh guru. Guru mendorong anak didiknya mengira atau menerka sesuatu terutama ketika jawaban yang dilontarkan masuk akal (Mayeski 2009).

\section{Mengembangkan Kreatifitas Anak-Anak melalui Pembelajaran (Kurikulum).}

Beberapa prinsip perlu dipertimbangkan, yaitu: kurikulum semestinya dirancang secara tepat untuk anak, memilih materi dan kegiatan yang bermanfaat dan relevan dengan kebutuhan anak. Juga guru menyiapan beragama bahan yang dapat mendorong eksplorasi kreatif anak yakni memberikan waktu yang memadai kepada anak-anak untuk menetapkan apa yang akan dilakukan. Guru mempertimbangkan tipe atau gaya belajra dan kecerdasan multiple. Para anak didik didorong untuk berfikir divergen dan memiliki rasa ingin tahu yang tinggi. Guru menyiapkan sistim point untuk setiap pertanyaan anak yang menunjukan keingintahuan. Juga guru memberikan kesempatan banyak kepada anaka-anak didik untuk berinterkasi dan berkomunikasi dengan temannya dan orang dewasa dalam atmosfer 
yang merasa diterima. Pembelajran yang mendorong tumbuhnya kreatif dilakukan dengan berbagai bentuk, misalnya, melalu eksperimen pelajaran sain dan diskusi suatu isu (Mayesky 2009).

a) Kurikulum terpadu (Integrated Curriculum). Kurikulum dirancang berdasarkan tema atau proyek kelas. Unit pembelajaran terdiri dari kegiatan pembelajaran berseri yang dirancang berdasarkan topik besaran yang melibatkan seluruh kelompok. Topik ini mengandung unit area pembelajaran seperti membaca, matematik, sain, ilmu sosial dan menyiapkan atau memberikan topik dan framework perencanaan kegiatan untuk anak didik. Anak didik secafra keseluruhan mencoba mengalami (Mayesky 2009).

b) Differentiated Instruction (DI). DI adalah cara berfikir tentang pembelajaran yang didasarkan kepada prinsip atau pandangan sebagai berikut: (a)Anak dalam usia sama memilki perbedaan dalam beberapa hal yaitu kesiapan belajar, minat, gaya belajar [styles of learning], dan pengalaman. (b) Perbedaan tersebut mempengaruhi apa yang peru dipelajari anak didik dan tugas utama guru dan sekolah adalah memaksimalkan kemampuan setiap anak didik. (c) Juga DI merupakan usaha perbaikan untuk mencapai mutu tinggi kurikulum dan pembelajran dan anak didik terlibat dalam menetpkan tujuan. (d) Kurikulum mempunyak hubungan dengan pengalaman dan minat anak didik. Oleh sebab itu DI dimaksudkan untuk memaksimalkan pertumbuhan anak dan membantu anak mencapai suatu kemajuan (Mayesky 2009).

\section{Penciptaan Wahana Kreatif}

Proses pengajaran dan pembelajarn semata tidak cukup untuk dapat membentuk dan menumbuhkembangkan sikap dan motivasi kreatif pada anak didik. Oleh sebab itu, diperlukan sarana yang dapat secara sinambung memelihara dan mempertahankan sikap dan motivasi anak didik berproses kreatif secara ajeg. Penciptaan wahana kreatif menjadi stimulan yang selalu 
hadir dan menggugah siswa untuk berkreasi. Guru memainkan peran sebagai sponsor kreatifitas yaitu guru melakukan kegiatan yang mendorong anak didik terlibat melalui pemberian hadiah terhadap suatu prilaku kreatif, memberikan kesempatan untuk mencapai prestasi (sukses); menfasilitasi tumbuhnya kemampuan berfikir divergent dengan memberikan kesempatan kepada anak didik mengkomunikasikan ide mereka kepada orang kain dan mengakui atau menghargai gagasan kreatif atau kemampuan berfikir divergent. Guru dapat memberikan kesempatan lebih leluasa kepda anak didik untuk "bermain" dengan masalah, material dan ide atau menyuntik fantasi sebagai sumber ide. Hal ini dapat dilakukan melalui kegiatan-melakukan science fair untuk mengekhibisikan mesin-mesin yang akan diproduksi atau dibutuhkan masa mendatang, mengorganisasi festival drama dengan tema-tema masa datang dan fantasi atau menyuruh anak-anak didik mendeskripsikan kejadian histories yang bakal terjadi (Cropley 1997).

\section{Penyediaan institusi dan Event Kreatif}

Untuk menciptakan Wahana Kreatif, maka di luar institusi sekolah diperlukan pula institusi lain yang merasa berkomitmen dan bertanggung jawab untuk membangun suasana pendidikan kreatif bagi siswa. Institusi ini tidak terbatas pada institusi dan lembaga pemerintah, namun juga harus meluas pada pemberdayaan semua institusi di masyarakat agar tumbuh kesadaran pada mereka akan arti pentingnya proses berpikir kreatif agar pada proses berikutnya dapat menjadi landasan bagi penumbuhan kesadaran untuk mengembangkan Ekonomi Kreatif. Suciu Marta-Christina dari Bucharest Academy of Economic Studies, Faculty of Economics, Economics and Economic Policies Department menyatakan bahwa prasyarat terbentuknya Ekonomi Kreatif adalah Urban Development dan Community yang mendukungnya. Sedangkan Florida (2005), dari university of Toronto menyatakan bahwa penciptaan Wahana Kreatif juga didukung oleh apa yang ia namakan "Creative Class", yang menurut pengaamatannya dapat 
menjadi pendorong untuk pengembangan ekonomi kota-kota di Amerika setelah era pasca industri. Tiga kelompok Creative Class disebutkan oleh Florida ialah Supercreative Core, Creative Professional dan Bohemian. Selain institusi dan Creative Class, institusi yang juga penting untuk pengembangan Wahana Kreatif adalah rumah/keluarga sebagai kelompok terkecil dalam masyarakat. Rumah atau keluarga seharusnya menjadi awal dari stimulasi proses pembelajaran kreatif bagi siswa yang dalam kelanjutan dan pengembangan akses hubungan berikutnya dengan institusi lain di luar rumah dapat diharapkan memperteguh sikap dan pola prilaku yang terbiasa bersikap kreatif.

\section{Pemberian Penghargaan atas Kreativitas}

Ajang lain yang tidak kalah penting untuk membangun Wahana Kreatif adalah adanya perlakuan yang konsisten berupa penghargaan, pengakuan, pujian, akan karya kreatif mereka. Siswa yang secara konsisten mendapatkan pengakuan dan penghargaan yang proporsioanal akan hasil karyanya, utamanya yang bernilai kreatif, merasa mendapatkan tempat akan prestasinya, sehingga dapat menumbuhkan rasa percaya diri dan konsep diri yang positif. Selain itu juga akan terbentuk sikap dan prilaku selalu ingin berkarya, sikap optimis dan antusias bahwa ia bisa berprestasi dan prestasi itu diapresiasi secara terbuka. Perlakuan ini akan mempertahankan motivasi siswa untuk terus berkreasi, sehingga pada akhirnya menjadi suatu kebutuhan dasar dan motivasi intrinsiknya untuk menunjukan kemampuannya sebagai bagian dari kontribusi dan tanggung jawab pribadinya pada lingkungan di sekitarnya. Pemberian penghargaan ini menjadi tanggung jawab semua pihak di masyarakat.

\section{F. Catatan Penutup}

Penilan pengajaran dan pembelajaran proses kreatif ditujukan pada dua sasaran. Pertama, evaluasi pada proses mental berpikir kreatif yang telah terbentuk melalui pembelajaran itu; dan kedua, hasil kreatifitas yang dapat berbentuk gagasan dan 
Dunia Pendidikan dan Pengembangan Daya Kreatif

produk benda/bentuk, yang mungkin sudah final sifatnya atau masih sementara. Evaluasi terkait proses mental yang terbentuk pada siswa dapat menggunakan ciri ciri perilaku berikut ini sebagai patokan: apakah pada siswa terbentuk sikap antusias/ bersemangat untuk berkreasi, sikap bertanggung jawab akan hasil gagasan/kreasinya, peningkatan kemahiran/teknik berkreasi, penguasaan materi/ tema ajang kreasinya, sikap bereksplorasi, prilaku kerjasama yang kondusif dan efektif, optimalisasi kerja individual, tumbuhnya rasa percaya diri, dan keterbukaan dan kemauan untuk mempresentasikan hasil ( "sementara").

Evaluasi dari hasil proses kreatif dapat diukur seperti yang dilakukan oleh Torrance (1966). Dalam evaluasi ini indikator yang diukur adalah berpikir divergen dan kemampuan problem solving yang dinilai dari skor Fluency, banyaknya gagasan yang dialirkan, Flexibility, lincahnya gagasan berpindah dari satu tema ke tema lain, Originality - keaslian dan keunikan gagasan, dan Elaboration - pendalaman dan rincinya gagasan yang dapat diuraikan. Ia mengembangkan the Torrance Test of Creative Thinking (TTCT) untuk mengukur seberapa pemikiran seseorng menyimpang dari suatu norma untuk mengkaji kreatifitas. Juga Torrance mengembangkan the Thinking Creatively in Action and Movement (TCAM) karena ia menyadari bahwa respon verbal dan tertulis tidak cukup memadai untuk anak-anak, yaitu, anakanak pre sekolah dan Taman Kanak-kanak. Usaha lain dapat dilakukan dengan apa yang disebut analog sebagai intelligence quotient (IQ) , ialah Creativity Quotient (CQ), sekalipun penilaian ini masih menjadi pro kontra di antara para ahli yang mengukur kreativitas.

Pendekatan psikometrik Guilford (1967) mengukur misalnya beberapa hal sebagai indikator terjadinya proses berpikir dan bertindak kreatif. Misalnya melalui kecepatan mengalirkan ide atau gagasan dari stimulus yang diberikan, menciptakan judul sebanyak mungkin dari suatu cerita yang diberikan, membuat gambar sebanyak banyaknya dari rangsang gambar yang diberikan, dan sebagainya. Guilford mengidentifikasi komponen utama dari karya [befikir] divergen yang telah 
menjadi tulang punggung beberpa riset dan penilaian (assessment) kreatifitas. Yaitu fluency (memunculkan atau melahirkan beberapa gagasan), flexibilitas (memunculkan atau melahirkan beberapa jenis gagasan yang berbeda dari cara pandang yang berbeda), originalitas (memunculkan atau melahirkan gagasan yang aneh atau tidak lumrah), dan elaborasi (menambah ide-ide untuk memperbaiki gagasan). Guilford identifikasi dua kategro kemampuan kreatif ["slab/blok" berfikir divergen dan transformsi, kemampuan memperbaiki yang dialami seseorang atau diketahui untuk melahirkan bentuk/gagasan baru (Starko 2010).

\section{DAFTAR PUSTAKA}

AI-Girl, Tan. 2007. Creativity: A Handbookfor Teacher. New Jersey: World Scientific.

Anetta, Leonard A, Shawn Y Holmes, David Vallet, Mathew Fee, Rebecca Cheng and Richard Lamb. 2011. "Cognitive Asspects of Creativity: Science Learning Through Serious Educational Games." In Teaching Creatively and Teaching Creativity, edited by Mary Bank Gregerson, Heather T. Snyder, and James C Kaufman. New York, Hedderber, London: Springer.

Ronald J. Baker. 2008. Mind Over Matter: Why Intellectual Capital is The Chief Source of Wealth. New Jersey: John Wiley and Sons, Inc.

Best, Brin and Will Thomas. 2008. The Creative Teaching and Learning Resource Book. New York: Continuum International Publishing Group.

Burnouf, Laura. 2004. "Global Awareness and Perspectives in Global Education.” Canadian Social Studies 38 (3).

Cohen, Robin and Paul Kennedy. 2000. Global Sociology. New York: Global Sociology.

Carnoy, Martin. 1999. Globalization and Education Reform: What Planners Need to Know Paris: UNESCO.

Craft, Anna. 2005. Creativity in Schools Tensions and Dilemmas. USA, Canada: Routhledge. 
Dunia Pendidikan dan Pengembangan Daya Kreatif

Craig, Cheryll J and Louise J. Deretchin. 2011. Cultivating Curious and Creative Minds: The Roles of Teachers and Teacher Educator: Part II Teacher Educator Yearbook XIX. Maryland, Playmouth UK, Toronto: Rowman and Littlefield Education.

Cropley, Arthur J. 1997. More Ways than One: Fostering Creativity. Norwood, New Jersey: Ablex Publishing Corporation.

Dunn, Dana S., Jane S. Halonen and Randolph A. Smith. 2008. Teaching Critical Thinking in Psychology: A Handbook of Best Practices. Oxford: Willey-Blackwell.

Fisher, Robert. 2004. "What is creativity?" in Unlocking Creativity: Teaching Across the Curriculum, edited by Robert Fisher and Mary William. London: David Fulton Publisher.

Fisher, Robert and Mary Williams. 2004. Unlocking Creativity: Teaching Across the Curriculum. London: David Fulton Publisher.

Fachruddin, Fuad. 2010. "Pendidikan Karakter: Beberapa Isu". Makalah Seminar Internasional diselenggarakan oleh Program Pasca Sarjana (PPS) IAIN Raden Fatah Palembang bekerja sama dengan Pemda OKU dan Pagar Alam, 17 and 18 Mei 2010.

Fachruddin, Fuad. 2008. "SBI (Sekolah Berstandar Internasional)/ Global School dan Internasionalisasi Pendidikan". Makalah Panel Diskusi dalam Pameran Buku Nasional 29 Juni 2008, dimuat dalam surat Kabar Media Indonesia.

Howkins, John. 2002. The Creative Economy: How People Make Money from Ideas. England, New York: Clay Ltd.

Hui, Desmond, NG Chung-hung and Patrik Mok. 2005. A Study on Creativity Index. Hongkong: Centre for Cultural Policy Research, The University of Hong Kong.

Jeffrey, Bob and Peter Woods. 2003. The Creative School: A framework for success, Quality and Effectiveness. London, New York: Routledge Falmer.

Lavon, Jim. 2008. Creative Approaches to Physical Education: Helping children to achieve their true Potential. London, New York: Routledge. 
Moon, Jennifer. 2008. Critical Thinking: An Exploration of Theory and Practice. London, New York: Routledge Taylor Francis Group.

Roberts, Ann and Avril Harpley. 2007. Helping Children to be Competent Learners From Birth to Three. London, New York: Routhledge.

Starko, Alane Jordan. 2010. Creativity in the Classroom Schools of Curious Delight. Fourth Edition. New York: Routledge.

Steger, Manfred D. 2001. Globalism: The New Market Ideology. New York: Rowman and Littlefield Publishers, Inc.

Stevenson, Nancy. 2006. Young Person's Character Education Handbook. Indianapolish: JIST Publishing, Inc.

Ward, Thomas B. 2007. "The Multiple Roles of Educators in Children's Creativity." In Creativiy: A Handbook for Teachers, edited by Ai-Girl Tan. London, New York: World Scientific.

Weintraub, Sandra. 1998. The Hidden Intelligence: Innovation through Intuition. Oxford, Melbourne, New Delhi, Singapore, Johannesburg: Heinemann.

Zajda, Josheph. 2005. International Handbook on Globalisation, Education and Policy Research Global Pedagogies and Policies. USA, The Netherland: Springer. 